\title{
Genetic variants in guanylyl cyclase and phoshodiesterase affecting coronary disease risk
}

\author{
Heribert Schunkert
}

From 6th International Conference on CGMP: Generators, Effectors and Therapeutic Implications

Erfurt, Germany. 28-30 June 2013

Impaired guanylyl cyclase activity (sGC) may be considered as a cardio-vascular risk factor. In order to study such association with genetic tools, we investigated the role of the GUCY 1A3 locus in genomewide association studies as well as families with premature coronary artery disease. We discovered genomewide significance for association between rs7692387 with coronary artery disease/ myocardial infarction in the CARDIoGRAMplusC4D study. Moreover, we discovered mutations in the GUCY $1 \mathrm{~A} 3$ gene in families with premature coronary disease. Functional studies revealed that impaired guanylyl cyclase activity was the most likely functional link between the genetic variations and the increased risk of coronary disease.

Submit your next manuscript to BioMed Central and take full advantage of:

- Convenient online submission

- Thorough peer review

- No space constraints or color figure charges

- Immediate publication on acceptance

- Inclusion in PubMed, CAS, Scopus and Google Scholar

- Research which is freely available for redistribution 